\title{
Pengembangan Media Permainan Game Geo Bus (GGS) untuk Mengenalkan Bentuk-Bentuk Geometri pada Anak Usia 4-5 Tahun
}

\author{
Desti Helfianti ${ }^{1 凶}$, Ria Novianti ${ }^{2}$, Yeni Solfiah ${ }^{3}$ \\ $(1,2,3)$ Pendidikan Guru Pendidikan Anak Usia Dini, Universitas Riau
}

$\triangle$ Corresponding author

(desti.helfianti5117@student.unri.ac.id)

\begin{abstract}
Abstrak
Penelitian ini bertujuan untuk mengetahui kelayakan yang diperoleh dari pengembangan produk game geo bus (GGS) bagi kemampuan mengenal bentuk-bentuk geometri pada anak usia 4-5 tahun. Jenis penelitian yang diambil yaitu penelitian pengembangan (Research and Development/R\&D), langkah-langkah yang dilakukan dalam penelitian Research and Development (R\&D) ini yaitu: potensi dan masalah; pengumpulan informasi; desain produk; validasi desain; revisi desain; validasi produk; revisi produk. Teknik pengumpulan data pada penelitian ini yaitu menggunakan kuisioner (angket), wawancara dan observasi. Instrument penelitian dilakukan dengan menggunakan lembaran kuesioner (angket). Instrument tersebut terdiri dari dua jenis validasi yaitu validasi instrument kelayakan produk dan instrument kelayakan materi. Teknik analisis data yang digunakan untuk penelitian ini adalah teknik analisis deskriptif kuantitatif. Dari hasil penelitian berdasarkan validasi yang didapat dari kedua validator dapat disimpulkan bahwa hasil validasi materi dan media tersebut, yaitu jumlah skor yang didapat dari gabungan kedua validasi materi, yaitu "41" skor, dengan rata-rata skor "4,5" dan kategori validasi materi yang didapat adalah "Sangat Layak". Sedangkan validasi media dengan jumlah " 45 " skor, dengan rata-rata skor "4,1", tentunya dengan kategori validasi media merupakan"Sangat Layak".
\end{abstract}

Kata Kunci: bentuk geometri, game geo bus (GGS), anak usia dini.

\begin{abstract}
This study aims to determine the feasibility of developing a geo bus (GGS) game product for the ability to recognize geometric shapes in children aged 4-5 years. The type of research taken is research development (Research and Development R\&D), the steps taken in this Research and Development (R\&D) research are: potentials and problems; information gathering; product design; design validation; design revision, product validation; product revision. Data collection techniques in this study were using questionnaires (questionnaires), interviews, and observations. The research instrument was carried out using a questionnaire sheet (questionnaire). The instrument consists of two types of validation, namely product eligibility instrument validation and material eligibility instrument. The data analysis technique used for this research is quantitative descriptive analysis technique. From the results of the research based on the validation obtained from the two validators, it can be concluded that the results of the material and media validation, namely the total score obtained from the combination of the two material validations, namely " 41 " score, with an average score of " 4.5 " and the validation category. The material obtained is "Very feasible". while the media validation amounted to "45" scores, with an average score of "4.1". Of course, the media validation category is "Very appropriate".
\end{abstract}

Keyword: geomentry shape, game geo bus (GGS), early childhood.

\section{PENDAHULUAN}

Pendidikan sangat penting bagi setiap individu, baik di Indonesia maupun Negara lain. Begitu pula dengan pendidikan bagi anak usia dini, dikatakan penting karena setiap individu pastinya mulai berproses sejak usia belia, salah satunya berproses dalam kegiatan belajar. Belajar di sini bukan hanya terfokus pada suatu hal yang dipenuhi oleh pembelajaran semata, namun yang lebih menariknya belajar yang dilaksanakan tersebut dilakukan sambil atau melalui bermain, hal tersebut tentunya didapatkan di sekolah pendidikan anak usia dini atau di lingkungan rumah.

Pendidikan anak usia dini (PAUD) itu sendiri merupakan suatu kegiatan pembelajaran yang menitikberatkan pada tujuan guna memenuhi segala aspek perkembangan dan pertumbuhan anak secara signifikan dan tentunya juga memenuhi semua aspek kepribadian anak (Suyadi dan Maulidya, 2013). 
Individu yang dinamakan sebagai anak usia dini menurut National Association for The Education for Young Children (NAEYC) berdasarkan dimensi usia kronologisnya yaitu anak yang berada pada rentang usia 0-8 tahun, yang tercakup dalam program pendidikan di taman penitipin anak, penitipan anak pada keluarga, pendidikan prasekolah baik swasta maupun negeri, TK dan SD (Safrudin, 2017).

Tidak salah jika banyak pihak berkata bahwa usia dini juga disebut dengan masa golden age, yaitu masa ketika seorang anak memiliki pertumbuhan dan perkembangan yang lebih pesat dibandingkan usia-usia setelahnya, yang mana perkembangan dan pertumbuhan tersebut membutuhkan stimulasi yang baik dan tepat. Menstimulasi demi merujuk segala aspek perkembangan anak sesuai tingkat perkembanganya sangat penting, karena awal masa perkembangan bagi anak tergolong lebih kritis dan lebih berharga yang nantinya perkembangan tersebutlah menjadi pangkal bagi perkembangan berikut sang anak.

Menurut Novan (2014) kemampuan geometri ada hubungannya dengan konsep bentuk dan ukuran, sehingga dalam kemampuan mengenal bentuk geometri tersebut harus dikembangkan demi kepentingan pengetahuan anak. Pengembangan yang dapat dikembangkan, yaitu: (1) Menyesuaikan bentuk geometri berdasarkan jenisnya; (2) Menyesuaikan geometri berdasarkan warna; (3) Menunjuk dan menyebut bentuk geometri (segitiga, segi empat, dan lingkaran); (4) Menyebut benda-benda di sekitar sesuai bentuk geometri (segitiga, segi empat dan lingkaran); (5) Mengelompokkan bentuk geometri; (6) Mencontohkan bentuk geometri.

Anak usia dini menurut Jean Piaget (dalam Agung Triharso, 2013) berada pada tahap intelektual masa pra-operasional, dimana masa ini lebih dominan pada pemikiran yang berkembang pada tatanan lebih baik dan mulai melibatkan simbol-simbol dalam memaknai suatu benda, serta mulai memahami pengertian dan konsepkonsep dengan menggunakan benda abstrak berdasarkan bayangan dan nalar anak, walaupun belum sepenuhnya terlepas dari benda konkrit terdekat anak. Dalam penelitian ini peneliti tertarik untuk mempelajari lebih lanjut tentang kemampuan mengenal bentuk-bentuk geometri pada anak usia dini.

Geometri merupakan bagian dari matematika dalam klasifikasi perkembangan kognitif berfikir secara logis yang akan dikembangkan untuk mengenali bentuk-bentuk geometri awal yang objeknya terdapat pada lingkungan sekitar (Lidia dkk, 2018).

Lestari K.W (dalam Lili Artika, 2017) menyatakan bahwa kemampuan mengenal bentuk geometri ialah kemampuan anak untuk mengenal, menunjukkan, menyebutkan, serta mengumpulkan benda-benda yang ada di sekitar anak berbentuk geometri berupa lingkaran, persegi, dan segitiga.

Sedangkan menurut Lailatul dan Mallevi (2019) pengenalan bentuk geometri itu sendiri merupakan pengenalan yang harus dilakukan oleh anak yang sama halnya dengan pengenalan bentuk benda di lingkungan sekitar, karena saling berkaitan satu sama lain, seperti bentuk jendela, koin, meja dan lain-lain, bertujuan untuk memenuhi kebutuhan anak untuk bermain.

Untuk memulai pembelajaran yang menyenangkan dibutuhkan lingkungan dan permainan yang menyenangkan pula, agar pembelajaran yang dilakukan terlaksana dengan menarik dan makna pembelajaran tersebut terpenuhi dengan semestinya. Mayke (dalam Agung Triharso, 2013) menyatakan bahwa kegiatan belajar sambil bermain dapat mendatangkan kesempatan bagi anak untuk memanipulasi, mengulang, menemukan sendiri, berekplorasi, mempraktikkan, dan mendapatkan berbagai konsep serta pengertian yang tidak terhingga bagi anak. Ketika proses pembelajaran berlangsung, anak-anak secara langsung maupun tidak langsung dapat mengambil keputusan, memilih, menentukan, menciptakan, memasang, membongkar, mengembalikan, mencoba, mengeluarkan pendapat, memecahkan permasalahan, mengerjakan secara tuntas, bekerja sama dengan teman, dan memahami berbagai bentuk perasaan dirinya maupun orang lain.

Kemampuan mengenal bentuk geometri dapat dikembangkan melalui media atau permainan yang sesuai dengan kebutuhan tersebut, tentunya permainan ini bertujuan dapat memusatkan perhatian anak sehingga kemampuannya tercapai. Salah satu permainan yang dapat digunakan yaitu Game Geo Bus (GGS). Game Geo Bus (GGS) merupakan permainan Bus Game yang diciptakan oleh Howard Gardner dan dimodifikasi menjadi permainan bus geometri.

\section{METODE PENELITIAN}

Jenis penelitian yang dipakai adalah penelitian pengembangan. Penelitian pengembangan (Research and Development/R\&D) menurut Sugiyono (2016) adalah metode penelitian yang digunakan oleh peneliti untuk menghasilkan suatu produk tertentu dan menguji keefektifan produk tersebut. Penelitian pengembangan berupaya menghasilkan produk tertentu yang dapat digunakan dalam penelitian, bersifat analisis kebutuhan dan memerlukan keefektifan agar produk tersebut berfungsi dengan cara menguji produk terlebih dahulu.

Sugiyono (2016) menunjukkan langkah penelitian Research and Development yang terbagi menjadi 10 bagian, antara lain yaitu: Potensi dan masalah, pengumpulan data, desain produk, validasi desain, revisi desain, uji coba produk, revisi produk, uji coba pemakaian, revisi produk, produksi masal. Dari 10 langkah tersebut, peneliti hanya mengambil 7 langkah pokok yang dapat dikerjakan, hal ini karena adanya suatu faktor penghambat yaitu berupa keterbatasan waktu, dana, dan tenaga. Adapun langkah-langkah yang dilakukan 
dalam penelitian Research and Development (R\&D) ini yaitu: Potensi dan masalah, Pengumpulan informasi, Desain produk, Validasi desain, Revisi desain, Validasi produk, dan Revisi produk.

Teknik analisis data yang digunakan untuk penelitian ini adalah teknik analisis deskriptif kuantitatif. Analisis data untuk kelayakan produk menggunakan penilaian hasil yang didapat dari ahli media pembelajaran dan ahli materi berupa instrument kuesioner (angket), sedangkan analisis data kelayakan produk oleh peserta didik akan dilakukan dengan instrument wawancara terbatas yang telah disediakan oleh peneliti untuk mengetahui apakah ada pengembangan permainan game geo bus (GGS) untuk anak usia 4-5 tahun terhadap kemampuan mengenal bentuk-bentuk geometri anak tersebut.

Dalam pengumpulan data ini menggunakan skala Likert dengan skala penilaiannya yaitu $1-5 \mathrm{skala}$. Hal ini memiliki makna, yaitu angka 1) tidak efektif, 2) kurang efektif, 3) cukup efektif, 4) efektif. dan 5) sangat efektif.

Menghitung skor rata-rata dari instrument dengan rumus, yaitu sebagai berikut:

$$
X=\left(\sum f x\right) / n
$$

Keterangan:

$X \quad$ :skor rata-rata

$\sum F X \quad$ : jumlah skor

$\mathrm{N} \quad$ : jumlah komponen validasi

Permainan game geo bus (GGS) dapat digunakan dengan baik apabila sesuai dengan kriteria validator layak dan sangat layak (valid)..

\section{HASIL DAN PEMBAHASAN}

Pengumpulan informasi dapat dilakukan dengan berbagai cara, baik itu berupa penyebaran angket, wawancara maupun observasi, karena hal tersebut tergantung kepada penelitian yang dibuat dan pengumpulan informasi yang dibutuhkan (lis Prasetyo, 2012). Observasi menurut Cartwright (dalam Ria Novianti, 2012) merupakan proses pengamatan dan pencatatan perilaku secara sistematis untuk tujuan pembuatan instruksi, manajemen dan layanan bagi anak.

Untuk mendapatkan informasi mengenai pengembangan kemampuan mengenal bentuk-bentuk geometri dan permainan yang umum digunakan, peneliti menggunakan metode wawancara dan observasi. Menurut Eti Hadiati dan Fidrayani (2019) wawancara merupakan interaksi yang dilakukan antara dua pihak yang bersangkutan untuk mendapatkan suatu informasi yang dilakukan secara langsung berupa keadaan yang ada pada tempat penelitian dengan tujuan tertentu. Sedangkan observasi menurut Cartwright (dalam Ria Novianti, 2012) merupakan proses pengamatan dan pencatatan perilaku secara sistematis untuk tujuan pembuatan instruksi, manajemen dan layanan bagi anak.

Wawancara tersebut ditujukan langsung kepada pihak-pihak sekolah yang bersangkutan (seperti guru, kepala sekolah, dan lain-lain) dengan memberikan pertanyaan-pertanyaan yang berkaitan dengan penelitian yang peneliti ambil. Sedangkan kegiatan observasi yaitu peneliti lakukan sendiri dengan cara terjun langsung ke beberapa sekolah untuk memperhatikan secara langsung bagaimana pengembangan geometri yang diajarkan di sekolah dan permainan yang digunakan untuk mengenalkan bentuk-bentuk geometri kepada anak.

Produk yang peneliti kembangkan yaitu berupa permainan transportasi daratan. Permainan ini pertama kali dibuat oleh Howard Gardner yaitu bernama Bus Game, permainan Bus Game ini diteliti guna bertujuan untuk mengembangkan kemampuan perhitungan permulaan bagi anak usia dini di masa tersebut, dengan ciri khas bus yang akan ditumpangi oleh penumpang memiliki empat rute perjalanan. Sedangkan yang peneliti kembangkan dan buat yaitu Game Geo Bus (GGS), permainan ini dirancang dan dikembangkan guna untuk perkembangan aspek pengetahuan anak yaitu logikal matematika, terkhususnya kemampuan mengenalkan bentuk-bentuk geometri kepada anak usia 4-5 tahun.

Dari beberapa permasalahan yang peneliti temui di lapangan, banyak anak usia 4-5 tahun tidak mengenal bentuk-bentuk geometri dan tidak mampu menyebutkan nama bentuk-bentuk geometri tersebut, serta mengelompokkannya sesuai jenis. Dari segi pengetahuan anak yang kurang dalam mengenal bentukbentuk geometri tersebut, ternyata di beberapa lembaga pendidikan Pendidikan Anak Usia Dini (PAUD) juga memiliki kendala dalam mengenalkan bentuk geometri tersebut, hal tersebut merupakan kurangnya sarana media atau alat permainan edukatif untuk mengenalkan bentuk geometri, media atau permainan yang digunakan kurang menarik, seringkali pembelajaran tersebut tidak membuat anak-anak berkembang pengetahuannya mengenai bentuk-bentuk geometri.

Menurut Eka Sri Hendayani (2012) bahwasanya untuk mencapai hasil pendidikan dan pembelajaran yang optimal harus didukung oleh aspek teknis dan non-teknis, hal ini merupakan sarana dan prasarana yang digunakan terkhususnya Alat Permainan Edukatif. 
Berdasarkan permasalahan di atas, peneliti mengembangkan dan membuat permainan yang termotivasi dari permainan bus game Howard Gardner. Permainan ini dirancang dan dikembangkan guna untuk perkembangan aspek pengetahuan anak yaitu logikal matematika, terkhususnya kemampuan mengenalkan bentuk-bentuk geometri kepada anak usia 4-5 tahun. Permainan ini peneliti beri nama Game Geo Bus (GGS).

Setelah produk selesai dibuat, langkah berikutnya yaitu produk tersebut divalidasi oleh validator, validator yang menilai produk yang peneliti kembangkan yaitu terdiri dari dua orang, satu orang ahli (dosen PG PAUD Universitas Riau) yaitu bapak Drs. Zulkifli N., M.Pd. untuk menilai validasi media dan validasi materi sebagai validator I dan satu orang ahli (dosen PG PAUD Universitas Riau) yaitu bapak Dr. Daviq Chairilsyah, M.Psi. untuk menilai validasi media dan validasi materi sebagai validator II. Setiap validator menilai dua validasi sekaligus (materi dan media/produk).

\section{Validasi materi produk}

Validasi materi produk bertujuan untuk menilai materi yang digunakan untuk pembuatan produk pengembangan, fungsinya untuk memperbaiki jika ada kekurangan yang didapat dari pembuatan materi sebelumnya. Validasi materi pertama dari validator I, dapat dilihat dari tabel berikut:

Tabel 1. Hasil Validasi Materi Validator I

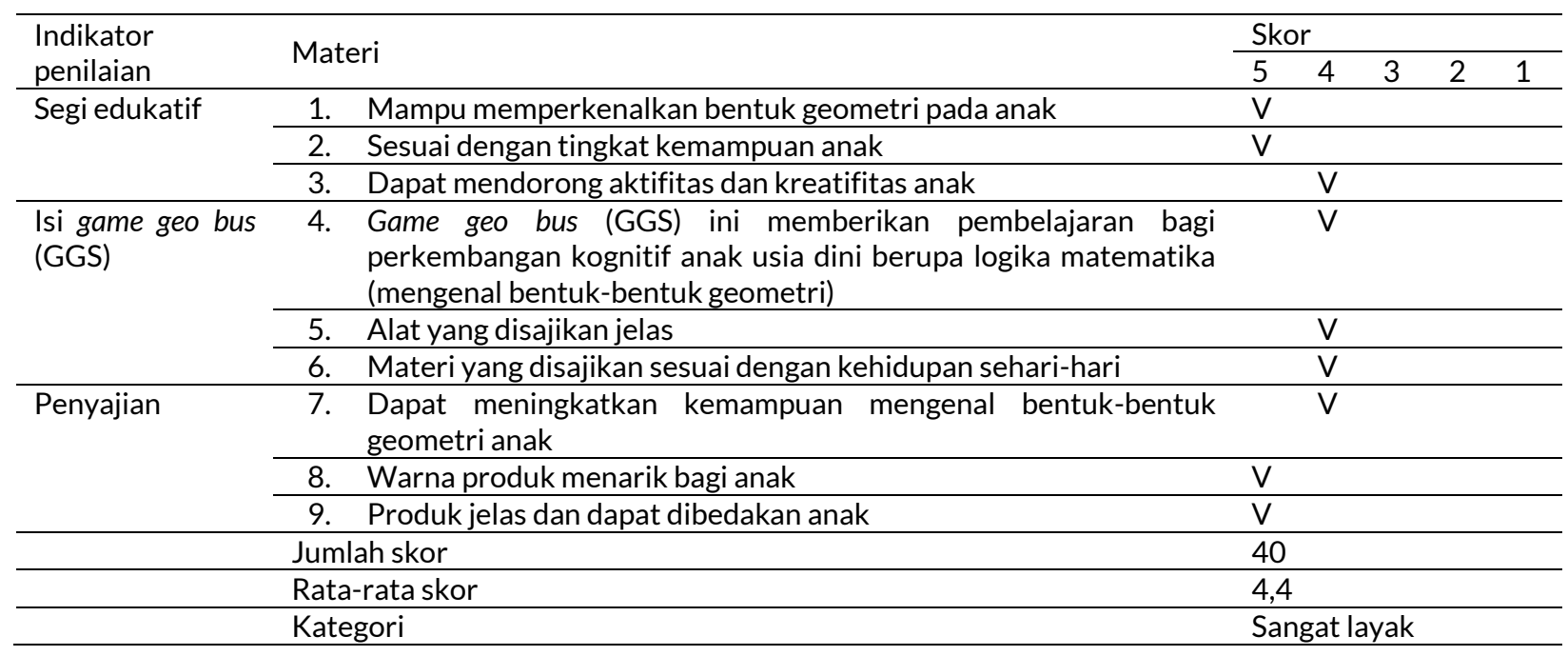

Berdasarkan tabel di atas, hasil validasi materi yang di dapat dari validator I yaitu memiliki jumlah skor berdasarkan skala likert sebanyak "42", dengan rata-rata skor "4,7", dan kategori validasi yang didapat berdasarkan interval validasi merupakan "sangat layak". Berikutnya merupakan hasil penilaian validasi materi dari validator II:

Tabel 2. Hasil Validasi Materi Validator II

\begin{tabular}{|c|c|c|c|c|c|c|}
\hline \multirow{2}{*}{$\begin{array}{l}\text { Indikator } \\
\text { penilaian }\end{array}$} & \multirow{2}{*}{ Materi } & \multicolumn{5}{|c|}{ Skor } \\
\hline & & 5 & 4 & 3 & 2 & 1 \\
\hline \multirow{3}{*}{$\begin{array}{l}\text { Segi } \\
\text { edukatif }\end{array}$} & 10. Mampu memperkenalkan bentuk geometri pada anak & $\mathrm{V}$ & & & & \\
\hline & 11. Sesuai dengan tingkat kemampuan anak & $\mathrm{V}$ & & & & \\
\hline & 12. Dapat mendorong aktifitas dan kreatifitas anak & & $\mathrm{V}$ & & & \\
\hline \multirow[t]{3}{*}{$\begin{array}{l}\text { Isi game geo } \\
\text { bus (GGS) }\end{array}$} & $\begin{array}{l}\text { 13. Game geo bus (GGS) ini memberikan pembelajaran bagi } \\
\text { perkembangan kognitif anak usia dini berupa logika matematika } \\
\text { (mengenal bentuk-bentuk geometri) }\end{array}$ & & $\mathrm{V}$ & & & \\
\hline & 14. Alat yang disajikan jelas & & $\mathrm{V}$ & & & \\
\hline & 15. Materi yang disajikan sesuai dengan kehidupan sehari-hari & & $\mathrm{V}$ & & & \\
\hline \multirow[t]{6}{*}{ Penyajian } & $\begin{array}{l}\text { 16. Dapat meningkatkan kemampuan mengenal bentuk-bentuk } \\
\text { geometrianak }\end{array}$ & & $\mathrm{V}$ & & & \\
\hline & 17. Warna produk menarik bagi anak & $\mathrm{V}$ & & & & \\
\hline & 18. Produk jelas dan dapat dibedakan anak & $\mathrm{V}$ & & & & \\
\hline & Jumlah skor & 40 & & & & \\
\hline & Rata-rata skor & 4,4 & & & & \\
\hline & Kategori & Sar & sat & yak & & \\
\hline
\end{tabular}


Dari uraian tabel 2 dapat dilihat, bahwa jumlah skor validasi berdasarkan skala likert yaitu "40", ratarata skor yang dihasilkan adalah "4,4", dan kategori validasinya yaitu "sangat layak".

Dari kedua tabel validasi materi yang dinilai oleh validator dapat disimpulkan dan ditarik hasilnya bahwa jumlah skor yang didapat dari gabungan kedua validasi, yaitu "41" skor, dengan rata-rata skor " 4,5 " dan kategori validasi materi yang didapat adalah "sangat layak".

\section{Validasi media}

Validasi media bertujuan untuk menilai hasil produk yang dibuat, dan berfungsi untuk memperbaiki kekurangan yang terdapat pada produk tersebut. Validasi media yang didapatkan dari validator I yaitu ditunjukkan dengan tabel di bawah ini:

Tabel 3. Hasil Validasi Media Validator I

\begin{tabular}{|c|c|c|c|c|c|c|}
\hline \multirow{2}{*}{ Indikator penilaian } & \multirow{2}{*}{ Materi } & \multicolumn{5}{|c|}{ Skor } \\
\hline & & 5 & 4 & 3 & 2 & 1 \\
\hline \multirow[t]{2}{*}{ Fisik } & 1. Warna yang digunakan menarik & & $\mathrm{V}$ & & & \\
\hline & 2. $\quad$ Bentuk produk sesuai dengan isi materi & & $\mathrm{V}$ & & & \\
\hline \multirow{3}{*}{$\begin{array}{l}\text { Segi } \\
\text { keindahan }\end{array}$} & 3. Bentuk yang menarik & & $\mathrm{V}$ & & & \\
\hline & 4. Kesesuaian ukuran & & $\mathrm{V}$ & & & \\
\hline & 5. Kombinasi warna yang serasi & & $\mathrm{V}$ & & & \\
\hline \multirow[t]{9}{*}{ Teknik pembuatan } & 6. Kebenaran & & $\mathrm{V}$ & & & \\
\hline & 7. Ketelitian (tidak menimbulkan salah konsep) & & $\mathrm{V}$ & & & \\
\hline & 8. Keawetan (kuat dan tahan lama) & & $\mathrm{V}$ & & & \\
\hline & 9. Ketahanan & & $\mathrm{V}$ & & & \\
\hline & 10. Keamanan & & $\mathrm{V}$ & & & \\
\hline & 11. Ketetapan ukuran & & $\mathrm{V}$ & & & \\
\hline & Jumlah skor & 44 & & & & \\
\hline & Rata-rata skor & $4,($ & & & & \\
\hline & Kategori & & & & & \\
\hline
\end{tabular}

Berdasarkan tabel 3, dapat dilihat hasil dari penilaian validasi media tersebut oleh validator I yaitu, memiliki "44" jumlah skor, dengan "4,0" rata-rata skor, dan kategori validasinya adalah "Layak". Berikut merupakan hasil penilaian dari validator II untuk validasi media:

Tabel 4. Hasil Validasi Media Validator II

\begin{tabular}{|c|c|c|c|c|c|}
\hline \multirow{2}{*}{$\begin{array}{l}\text { Indikator } \\
\text { penilaian }\end{array}$} & \multirow{2}{*}{ Materi } & \multicolumn{4}{|l|}{ Skor } \\
\hline & & 54 & 3 & 2 & 1 \\
\hline \multirow[t]{2}{*}{ Fisik } & 1. Warna yang digunakan menarik & $\mathrm{V}$ & & & \\
\hline & 2. Bentuk produk sesuai dengan isi materi & $\mathrm{V}$ & & & \\
\hline \multirow{3}{*}{$\begin{array}{l}\text { Segi estetika/ } \\
\text { keindahan }\end{array}$} & 3. Bentuk yang menarik & $\mathrm{V}$ & & & \\
\hline & 4. Kesesuaian ukuran & $\mathrm{V}$ & & & \\
\hline & 5. Kombinasi warna yang serasi & $\mathrm{V}$ & & & \\
\hline \multirow{9}{*}{$\begin{array}{l}\text { Teknik } \\
\text { pembuatan }\end{array}$} & 6. Kebenaran & $\mathrm{V}$ & & & \\
\hline & 7. Ketelitian (tidak menimbulkan salah konsep) & $\mathrm{V}$ & & & \\
\hline & 8. Keawetan (kuat dan tahan lama) & $\mathrm{V}$ & & & \\
\hline & 9. Ketahanan & $\mathrm{V}$ & & & \\
\hline & 10. Keamanan & $\mathrm{V}$ & & & \\
\hline & 11. Ketetapan ukuran & $\mathrm{V}$ & & & \\
\hline & Jumlah skor & 46 & & & \\
\hline & Rata-rata skor & 4,2 & & & \\
\hline & Kategori & Sangat & yak & & \\
\hline
\end{tabular}

Berdasarkan tabel 4, dapat diuraikan hasil validasi media yang dinilai oleh validator II, yaitu jumlah skor validasi yang didapat " 46 " skor, dengan rata-rata skor "4,2", dan kategori validasi yang diperoleh adalah "Sangat Layak".

Dari kedua tabel validasi media tersebut, dapat disimpulkan hasil validasi dari kedua validator, yaitu dengan jumlah skor " 45 " skor, dengan rata-rata skor "4,1", tentunya dengan kategori validasi media merupakan"Sangat Layak".

Pengumpulan informasi mengenai potensi dan masalah merupakan langkah awal dari penelitian pengembangan ini, potensi masalah yang banyak peneliti temukan tentang alat permainan edukatif atau media yang digunakan untuk mengenalkan bentuk-bentuk geometri kepada anak adalah pokok permasalahan 
utama. Pengenalan bentuk geometri itu sendiri menurut Lailatul dan Mallevi (2019) merupakan pengenalan yang harus dilakukan oleh anak yang sama halnya dengan pengenalan bentuk benda di lingkungan sekitar, karena saling berkaitan satu sama lain, seperti bentuk jendela, koin, meja dan lain-lain, bertujuan untuk memenuhi kebutuhan anak untuk bermain.

Pengenalan geometri dapat dikenalkan kepada anak sesuai dengan tahapan-tahapannya. Van Hiele (dalam Devi, 2019) menyatakan bahwa ada lima tahapan dalam mengenal bentuk-bentuk geometri untuk anak usia dini, yaitu antara lain: (a) tahap pengenalan yaitu anak-anak dapat mengenal geometri melalui lingkungan sekitar, namun belum mengetahui sifat-sifatnya; (b) tahap analisis yaitu anak sudah mampu mengetahui sifat geometri tersebut dari benda yang diamatinya; (c) tahap pengurutan yaitu anak sudah mampu berpikir deduktif dan menarik kesimpulan dari benda berbentuk geometri yang dilihatnya; (d) tahap deduksi yaitu anak sudah mampu menarik kesimpulan secara deduksi dari hal yang bersifat umum ke yang bersifat khusus; (e) tahap akurasi yaitu anak mulai menyadari pentingnya ketetapan dalam mengenali bentuk geometri dan mempelajarinya melalui benda-benda konkret.

Untuk mengenalkan bentuk-bentuk geometri kepada anak perlu disampaikan melalui permainan yang dapat dimainkan oleh sang anak. Permainan merupakan suatu kegiatan rekreasi bertujuan untuk kesenangan, mengisi luang waktu, atau berolahraga ringan yang dilakukan secara individual atau bersamasama (Dasrun, 2013). Permainan tersebut dapat berupa media atau alat permainan edukatif. Media pembelajaran ini haruslah membantu guru untuk memenuhi pembelajaran yang ada dan tentunya sangat penting bagi berjalanannya suatu proses pembelajaran, serta diharapkan dapat menumbuhkan dampak positif bagi perkembangan anak (Sukma, Ria, \& Daviq, 2020)

Sedangkan bermain itu sendiri menurut Hurlock (dalam Rita, 2011) merupakan merupakan kegiatan yang dilakukan oleh individu demi mencapai kesenangan tanpa mempertimbangkan hasil akhir, yang dilakukan dengan suka rela tanpa adanya tekanan dan paksaan dari individu/sekelompok lain.

Mengenalkan bentuk-bentuk geometri kepada anak usia 4-5 tahun tidaklah sulit dan dapat dilakukan secara menarik agar anak dapat mengenal bentuk geometri tersebut dengan baik, namun masih banyak lembaga pendidikan Pendidikan Anak Usia Dini (PAUD) yang tidak memanfaatkan hal tersebut, karena adanya keterbatasan sarana dan prasana maupun kreativitas dari tenaga pendidiknya.

Setidaknya yang dikembangkan oleh lembaga pendidikan adalah alat permainan edukatif. Permainan edukatif seharusnya merupakan kegiatan pertama dan utama yang digunakan untuk pengembangan aspek pendidikan anak, sebab hanya dengan hal tersebut anak dapat merangsang kemampuannya (Abdul Khobir, 2009).

Produk pengembangan yang peneliti buat merupakan permainan transportasi darat yang diberi nama game geo bus (GGS) yang dimodifikasi dan dikembangkan melalui permainan bus game yang diciptakan oleh Howard Gardner. Permainan Bus Game ini diteliti guna bertujuan untuk mengembangkan kemampuan perhitungan permulaan bagi anak usia dini di masa tersebut, dengan ciri khas bus yang akan ditumpangi oleh penumpang memiliki empat rute perjalanan. Anak yang memainkan permainan ini terdiri dari dua orang, yaitu sebagai supir bus (menjalankan bus) dan pengamat (mengamati berapa orang yang naik dan turun dari bus, serta menghitungnya).

Sedangkan permainan game geo bus (GGS) yang peneliti buat bertujuan untuk mengenalkan bentukbentuk geometri kepada anak dengan menggunakan bentuk geometri (berupa balok segitiga, lingkaran, dan segi empat) untuk mengganti orang-orang pada media yang asli, dan menggunakan kartu bergambar bentuk geometri yang ada pada kehidupan nyata (seperti gambar bola, caping, meja dan lain-lain) untuk menggati CIP pada media yang asli. Anak yang berperan sebagai pengamat harus memperhatikan bentuk-bentuk geometri yang naik dan turun pada bus, dan mengeluarkan kartu yang ada pada kotak sesuai dengan yang diamati oleh anak. Hasil akhir dari permainan ini, anak yang berperan menjalankan bus mengeluarkan bentuk yang ada pada bus tersebut, lalu menyebut nama dari bentuk geometri tersebut, dan anak kedua yang berperan sebagai pengamat memperlihatkan semua kartu yang ia keluarkan dari kotak, apakah sesuai dengan hasil akhir yang ada pada bus, dan anak tersebut menyebutkan kembali nama bentuk-bentuk geometri serta menyebutkan gambar bentuk geometri yang dikeluarkan anak tersebut dari kotak.

Produk permainan ini sudah dibuat dan divalidasi oleh 2 validator ahli, yaitu setiap validator menilai kedua validasi sekaligus (validasi materi dan validasi media). Hasil validasi yang didapat dari pengembangan produk game geo bus (GGS) ini, antara lain:

\section{Hasil penilaian validator materi}

Berdasarkan validasi materi yang dinilai oleh validator, terdapat beberapa aspek yang harus dinilai oleh kedua validator tersebut, hal tersebut ialah: dari Segi edukatif, Isi game geo bus (GGS), dan Penyajian. Hasil penilaian yang didapat dari validator I ialah: jumlah skor "42", dengan rata-rata skor "4,7" dan kategori validasi "sangat layak". Sedangkan hasil penilaian dari validator II ialah: jumlah skor "40", dengan rata-rata skor "4,4", dan kategori validasi "sangat layak". Hasil kesimpulan dari penilaian kedua validator ialah: dengan jumlah skor "41", rata-rata skor "4,5", dan validasi kategori materi akhir yang diperoleh adalah "Sangat Layak" 


\section{Hasil penilaian validator media}

Validasi media juga dinilai dengan melihat beberapa aspek yang harus divalidasi oleh kedua validator, aspek-aspek tersebut antara lain: fisik, segi estetika/keindahan, dan teknik pembuatan. Dari ketiga aspek tersebut dapat dilihat hasil penilaiannya dari kedua validator. Hasil penilaian validasi media oleh validator I adalah: jumlah skor validasi "44", dengan rata-rata skor "4,0", dan kategori validasi yang didapat "layak". Hasil penilaian validasi media oleh validator II adalah: jumlah skor validasi "46", dengan rata-rata skor validasi "4,2", dan kategori validasi yang dihasilkan "sangat layak". Dari kedua hasil validasi tersebut dapat disimpulkan dan diambil hasil rata-rata penilaiannya, yaitu: jumlah skor validasi "45", rata-rata skor validasi "4,1", dan kategori validasi media akhir yang diperoleh "Sangat layak".

\section{Hasil analisis biaya akhir}

Setelah produk sudah berhasil dibuat, maka biaya yang dapat dikeluarkan untuk pembuatan produk permainan game geo bus (GGS) ini, antara lain: (a) biaya pembelian bahan (kayu, triplek, cat acrylic, kertas, plastik, paku kecil, stapler, dan lain-lain): Rp 200.000; (b) biaya pembelian alat-alat (gergaji kecil, palu, kuas cat, dlI): Rp 150.00; (c) biaya percetakan: Rp 20.000

Berdasarkan penilaian dari kedua validator, menyatakan permainan game geo bus (GGS) ini sangat layak digunakan guna membantu lembaga pendidikan untuk mengenalkan bentuk-bentuk geometri kepada anak usia dini. Kelayakan tersebut dilihat dari segi materi dan produk yang dihasilkan. Dari segi materi yaitu produk yang dihasilkan harus sesuai dengan tingkat kemampuan anak, dapat mendorong aktifitas dan kreatifitas anak, yang disajikan sesuai dengan keadaan atau gambaran sehari-hari, dapat meningkatkan kemampuan pengenalan anak tentang mengenal bentuk-bentuk geomerti. Sedangkan dari segi produk yaitu produk yang dikembangkan menarik, mudah dimainkan oleh anak, memiliki ketahanan, keamanan, dan ketepatan ukuran yang baik, dan warna yang bagus. Menurut Azhar Arsyad (dalam Aryuni, Yeni, \& Rita, 2020) dalam desain produk, pemberian warna yang menarik merupakan suatu keunggulan dari produk yang dibuat karena dapat memberikan dampak psikologis bagi penikmatnya.

Menurut Zaman Badru (dalam Dian, 2017) ciri-ciri permainan alat edukatif yang baik bagi anak yaitu dirancang sesuai dengan rentang usia anak, berfungsi untuk mengembangkan segala aspek perkembangan anak (seperti kognitif, motorik, bahasa, nilai agama dan moral, seni, sosial emosional), aman digunakan anak, dan dapat mendorong kreativitas dan aktifitas peserta didik.

Suyadi (dalam Dian, 2017) juga menjelaskan bagaimana ketentuan untuk melihat bahwa alat permainan edukatif tersebut mempunyai nilai edukasi yang tinggi dan positif bagi anak yaitu, sesuai perkembangan anak, menyenangkan, aman, dan mencerdaskan aspek yang dituju.

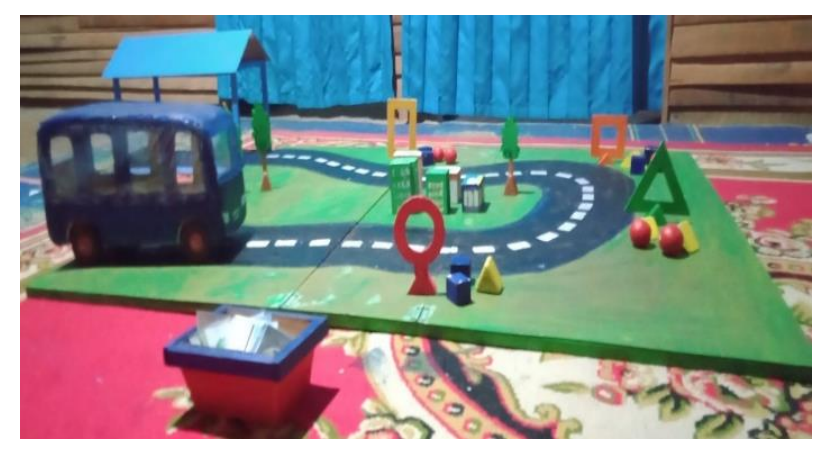

\section{Gambar 1. Media Permainan Game Geo Bus (GGS)}

\section{SIMPULAN}

Alat permainan edukatif yang dikembangkan melalui penelitian ini adalah permainan game geo bus (GGS), yaitu merupakan permainan untuk mengembangkan kemampuan mengenal bentuk-bentuk geometri kepada anak usia 4-5 tahun. Pengembangan ini tentunya memperhatikan aspek materi dan media, agar tujuan dari penelitian pengembangan berjalan dengan signifikan. Untuk membuat produk pengembangan harus dilakukan secara berkala, guna menghasilkan tampilan produk yang menarik sehingga diminati anak dan menghasilkan produk yang berfungsi untuk mengembangkan segala aspek perkembangan dan pertumbuhan anak terkhususnya perkembangan aspek kognitif yaitu logikal matematika (mengenal bentuk-bentuk geometri).

Hasil validasi yang diperoleh dalam pengembangan permainan game geo bus (GGS) ini sangat memuaskan. Hasil penilaian dari kedua validator dapat ditunjukkan sebagai berikut. Hasil validasi materi yaitu, dengan jumlah skor penilaian validasi " 41 ", rata-rata skor validasi sebanyak "4,5", yang artinya memiliki kategori validasi "sangat layak". Sedangkan hasil dari validasi media ialah, dengan jumlah skor validasi "45" dengan rata-rata skor "4,1", yang artinya memiliki kategori validasi "sangat layak". Kedua hasil kategori 
validasi menunjukkan "sangat layak", oleh karena itu pengembangan permainan game geo bus (GGS) ini tentu sangat layak digunakan oleh anak usia 4-5 tahun untuk meningkatkan pengetahuannya tentang pengenalan bentuk-bentuk geometri.

\section{UCAPAN TERIMA KASIH}

Penulis untuk mengucapkan ribuan terimakasih kepada: 1) Rektorat Universitas Riau yang telah memperikan kesempatan penulis untuk menuntut ilmu di Universita Riau, 2) Dekan Fakultas Keguruan dan Ilmu Pendidikan Universitas Riau yang telah memberi izin penelitian dalam proses penyelesaian skripsi, 3) Koordinator Prodi PG PAUD yaitu ibu Enda Puspita Sari, M.Pd, 4) Ibu Ria Novianti, S.Psi, M.Pd. selaku dosen pembimbing 1 dan ibu Yeni Solfiah, M.Pd. selaku dosen pembimbing 2 yang telah memberikan nasihat, masukan, dan semangatnya sehingga skripsi ini dapat terselesaikan dengan baik, 5) Bapak Drs. Zulkifli N., M.Pd. dan bapak Dr. Daviq Chairilsyah, M.Psi. selaku validator yang menilai validasi materi dan media peneliti, 6) Seluruh dosen Jurusan Ilmu Pendidikan yang telah memberikan ilmunya kepada penulis, sehingga penulis dapat menggunakan ilmu tersebut dengan baik, 7) Keluarga tercinta Ayah Hakimin, Mama Pitri Yanti, Adik Febrian Hikmah, dan Adik Effan Hakim Al-Siddiq yang selama ini telah memberikan dukungan dan semangatnya untuk menyelesaikan skripsi ini, 8) Kak Kodri Akbar Dikal yang selalu memberikan semangat dalam menyelesaikan skripsi ini, 9) Teman-temanku Nova Rosvika, Bunga Indra Pratiwi, Relwi Yani, Sri Wulan Dari, Sarah Putri Syafira, Novi Eka Saputri, Sri Masitah dan teman-teman seperjuangan "SQUAD ECE 2017 B" lainnya yang sudah membantu dan memberikan semangatnya untuk menyelesaikan skripsi ini.

\section{DAFTAR PUSTAKA}

Agung Triharso. 2013. Permainan Kreatif dan Edukatif Untuk Anak Usia Dini. Penerbit Andi. Yogyakarta.

Abdul Khobir. 2009. Upaya Mendidik Anak Melalui Permainan Edukatif. 7 (2). (Online). Repository.lainpekalongan.Ac.Id. (Diakses 08 November 2020).

Aryuni Rusdianti, Yeni Solfiah, \& Rita Kurnia. 2020. Pengembangan Media Getar (Geometri Putar) untuk Meningkatkan Kemampuan Mengenal Bentuk Geometri pada Anak Usia 4-5 Tahun. 3 (2). (Online). Https://journal.universitaspahlawan.ac.id. (Diakses 20 Desember 2020).

Dasrun Hidayat. 2013. Permainan Tradisional dan Kearifan Lokal Kampung Dukuh Garut Selatan Jawa Barat. 5 (02). (Online). Jurnal.untad.ac.id. (Diakses 17 Desember 2020).

Devi Purnama Sari. 2019. Pengaruh Permainan Kotak Misteri Terhadap Kemampuan Mengenal Bentuk Geometri Pada Anak Usia 4-5 Tahun Di TK Negeri Pembina 3 Kecamatan Marpoyan Damai Kota Pekanbaru. Universitas Riau. (Skripsi).

Dian Rahma. 2017. Penggunaan Alat Permainan Edukatif untuk Mendukung Perkembangan Anak Usia 5-6 Tahun di Paud Al Fikri. 6 (10). (Online). Academia.Edu. (Diakses 17 Desember 2020).

Eti Hadiati dan Fidrayani. 2019. Manajemen Pembelajaran Pendidikan Anak Usia Dini. 2 (1). (Online). http://ejournal.radenintan.ac.id. (Diakses 08 November 2020).

Eka Sri Hendayani. 2012. Pemanfaatan Alat Permainan Edukatif (Ape) Dalam Pembelajaran Paud Seatap Margaluyu Kecamatan Cipatat Kabupaten Bandung Barat. 1 (2). (Online). EJournal.Stkipsiliwangi.Ac.Id. (Diakses 08 November 2020).

lis Prasetyo. 2012. Teknik Analisis Data Dalam Research And Development. (Online). Academia.Edu. (Diakses 08 November 2020).

Lailatul Asmaul Chusna dan Mallevi Agustin Ningrum. 2019. Pengembangan Media Dakon Geometri Untuk Meningkatkan Kemampuan Mengenal Bentuk Geometri Anak Usia 4-5 Tahun. 8 (2). (Online). https://jurnalmahasiswa.unesa.ac.id. (Diakses 16 Maret 2020).

Lidia Safitri, dkk. 2018. The Effect of Geometry Box Media on the Ability to Know the Concept of Numbers and Geometric Shapes. 212. (Online). https://www.atlantis-press.com. (Diakses 16 Maret 2020).

Lili Artika. 2017. Pengaruh Permainan Dakon Geometri Terhadap Kemampuan Mengenal Bentuk Geometri Pada Anak Usia 4-5 Tahun Di Paud Dahlia Mandiri Desa Muntai Kecamatan Bantan Kabupaten Bengkalis. 4 (1). (Online). Http://Jom.Unri.Ac.Id. (Diakses 16 Maret 2020).

Novan Ardy Wiyani. 2014. Psikologi Perkembangan Anak Usia Dini. Gavamedia. Yogyakarta.

Ria Novianti. 2012. Teknik Observasi Bagi Pendidikan Anak Usia Dini. 1 (1). (Online). Educhild.Ejournal.Unri.Ac.Id. (Diakses 19 Juni 2020).

Rita Kurnia. 2011. Bermain dan Permainan Anak Usia Dini. Cendikia Insani Pekanbaru. Pekanbaru.

Safrudin Aziz. 2017. Strategi Pembelajaran Aktif Anak Usia Dini Panduan Bagi Guru, Orang Tua, Konselor, dan Praktisi Pendidikan Anak Usia Dini. Kalimedia. Yogyakarta.

Sugiyono. 2016. Metode Penelitian Kuantitatif, Kualitatif, dan R\&D. Alfabeta. Bandung.

Sukma Cania, Ria Novianti, \& Daviq Chairilsyah. 2020. Pengaruh Media Glowing City terhadap Kemampuan Mengenal Bentuk Geometri pada Anak Usia Dini. 3 (1). (Online). https://www.aulad.org/index.php/aulad/article/download/1210/955. (Diakses 20 Desember 2020).

Suyadi dan Maulidya Ulfah. 2013. Konsep Dasar Paud. Pt Remaja Rosdakarya. Bandung. 